\title{
Religious Education: Analysis over the Years
}

\author{
Afia Mushtaq Ramla Sadiq \\ Lecturer, Department of Economics Lecturer, Department of Finance \\ University of Management University of Management \\ and Technology, Lahore and Technology, Lahore
}

\author{
Farrukh Ijaz \\ Officer Academics \\ Institute of Islamic Banking \\ University of Management and Technology, Lahore
}

\begin{abstract}
The present study is an effort to gather research aspects for religious education in Pakistan. Religious education, most commonly known as madrasa education, has a profound history titled as Nizamiyah. Historical changes in the Muslim regions have influenced this mode of education as well. It has been argued by some researchers that positivity of faith based education has diminished due to the changes in international political and economical scenario. Terrorism was found to be a strongly associated variable with madrasa education and researchers have reasoned it with poverty, strong mentoring system and misconceptualizations of some religious beliefs. This study has found that while madrasas are perceived very negatively, research shows that there are positive influences regarding availability of education and women empowerment. The negativity is attributed largely to media misrepresentation and political interests.
\end{abstract}

Keywords: Faith, Madrasa, Religious Education

\section{Introduction}

The development of any country relies on its educational framework. Education is the way forward when it comes to the achievement of human advancement and social change. It is a useful instrument for the strengthening of an individual's capabilities. It helps in creating trust in individuals and groups about their own abilities, and thus enhances the innate qualities that shape their lives. In this way, education improves inward quality. Education is the method by which social orders have been known to transform from mistreatment to democratic interest and inclusion. On the premise of existing research, the developing consensus is that educational systems do not systematically affect student accomplishment - reality is developing against peculiar system based educational interventions. ${ }^{1}$

An increasing number of governments are favoring approaches in the light of encouragement, governance, extensive choices and competition. In this situation, the current point of convergence is on sorting institutional elements that are connected with better administration and accountability. One such institutional variable is faith orientation of the school. Different specialists contend that faith (e.g. Catholic) schools in developed nations are regulated by intrinsically motivated teachers and take after academic practices that give students an exceptional learning advantage over their non-faith or secular educated associates. ${ }^{2}$ Religious 
schools are not instantly recognizable in the Western education system. In nations with expansive Muslim populaces, there is a notable network of Islamic schools (otherwise known as madrasas). The present study focuses on research insight into the development of religious education in Pakistan over time. In order to do so, this study discusses socio political factors that changed the perception about the madrasa education that is known as religious education in Pakis$\tan$.

This study begins with a perspective on the evolution of religious seminaries and then discusses the current state of madrasas in Pakistan. Furthermore, it discusses the types of madaris and gender dynamics that are prevalent within these institutions. Connecting the religious education institutions with mainstream secular education, we discuss the relationship between madrasas and other educational institutions, and academic achievement in schools. Lastly, we emphasize the media misrepresentation of religious education and present concluding remarks.

\section{Evolution of Religious Seminaries in Pakistan}

The concept of religious education (seminaries/ madaris) is centuries old. During the $19^{\text {th }}$ and $20^{\text {th }}$ centuries, repeated attempts were made at reforming the religious seminaries in Muslim societies. Religious seminaries emerged as the primary institution of higher Islamic learning, and adapted degree programs to local cultures and changing times since the $11^{\text {th }}$ century. This section shows how particular concepts and categories of colonial analysis have shaped and continued to persist in much of the debate on the reform of the religious seminaries in Pakistan, and how the initiatives towards reform have cultivated perspectives of religion as possessing an unmistakable place in society.

Religious education spread quickly all through the Muslim world and despite the fact that their educational modules differed across geographies, it was constantly connected to the same underlying thread. This association is in light of the fact that the primary objective of these schools was to prepare future Islamic religious researchers. During the $11^{\text {th }}$ century, the Nizamiyah, the first established religious seminary was built in Baghdad offering shelter, food and free education. Laying great importance on the traditional Arabic linguistics, the teaching pedagogy of the institutions was based on learning by rote and testing the retention of memory.

Colonial policies were often confused and contradictory, and education was no exception. During the $19^{\text {th }}$ and early $20^{\text {th }}$ centuries, secular institutions came to supersede religious schools in importance throughout the Islamic world. Even among the latter, however, not all religious seminaries were reformed. However, religious institutes started to be revolutionized in the 1970s, with rising interest in Islamic studies in Iran and Pakistan.

The historical backdrop of madrasas in Pakistan can be traced back to the attainment of independence from the British in the subcontinent, trailed by a sudden rise in numbers amid Zia-ul-Haq's religious imperative when these theological schools mushroomed and were subsidized on the logic of Jihad. There were 
only 25 religious theological colleges when Pakistan gained independence but this number kept growing; however, the government has yet to pay serious attention to the reasons behind the growth and reliability of these institutions. In the 1980s, religious establishments in Pakistan were purportedly helped by an increase in financial resources from governments of Europe, Saudi Arabia and United States. They apparently saw these institutions as selecting pools for candidates of anti-Soviet warriors. The mid 1990s were characterized by the Taliban advancement. The word talib means student in Arabic language. The Taliban were guided mostly by Afghan Islamic pastors and represented alumni of madrasas. More importantly, these students represented a category of Muslims who maintained a very strict version of Islam, namely, Wahhabism which originated from Saudi Arabia.

\section{Current State of Madrasas in Pakistan}

Religious education in Pakistan maintains an essential position in the general educational system of the nation. The number of students registered in programs involving religious education in colleges and higher education institutes as well as customary religious education organizations such as madrasas is much higher than the number of students in any other area. ${ }^{3}$ Students that graduate from various programs offered in these institutions differ in skills, including presentation, communication and cultural orientation. While research shows that graduates from religious institutions are able to enter and achieve relative success in mainstream education, the case is not so when considering student transitions from mainstream education to religious education.

In recent years, governments and citizens of the United States, Europe and the Persian Gulf have expressed serious concerns over the radical widening of Islamic seminaries through schools, colleges, universities and masjids that are receiving endowment and curriculum material from international agencies. These international donor agencies originate from Southeast Asia, Middle East, SubSaharan Africa, North Africa, United States and Western Europe, to name a few. The international linkage of these donations to Islamic charities shows that the sources of funding can easily be associated with political undercurrents which shape the perceptions of these charities and their established institutes.

A number of foreign countries are of the view that the curriculum of these religious seminaries endorsed Islamic rituals in Pakistan and viewed it as being threatening to the judicial faith and belief system in other divisions of the Muslim population. Also, many international state governments claimed that there should be isolation between the funding to endow charitable projects, development of infrastructure of seminaries, curriculum material development, and between the funding that has been securely and unreservedly provided to support terrorist teachings in these religious institutions. According to Ali and Farooq, ${ }^{4}$ a large number of religious seminaries receive assistance and funding from Islamic charitable organizations across the world; yet accountability among the recipients and donor agencies remains unclear for educational control and curriculum development. 
The education system of Muslim countries is typically based on two key streams. The first stream comprises of public and private schools, colleges and universities that are providing Western education along with religious education. The second stream pertains to seminaries (Deeni Madaris) that have been established by different schools of thought and are controlled by independent waqaf boards to streamline educational regulations for these religious seminaries in the country. Despite the presence of various commonalities, both these education streams are different, with respect to curriculum, infrastructure setups, objectives and outcomes from each other. Accordingly, such substantial uncertainty in educational system of seminaries creates hurdles and causes a dilemma for the government and the official policy makers while assimilating the seminaries in a general policy highlighted by various scholarly and activist circles. ${ }^{5}$

Moreover, Afghan Taliban and Al-Qaida regimes' alleged links with some religious seminaries in Pakistan have led to reform proposals for Pakistan's religious education system. This was proposed by some observers as a means of helping to fight terrorism and stabilize the Pakistani and Afghan governments. Some members of the academia in the United States raise concerns about Pakistan's religious and educational infrastructure for harboring over 13,000 seminaries in the country. In recommending increased US interest to terrorist asylum, "The 9/11 Commission's final report singled out poor education in Pakistan as a particular concern, citing reports that some religious seminaries have been used as incubators for violent extremism. The registration may be greeted with hesitation by the madrassa owners who want to avoid regulations, monitoring and oversight. This is due to many reasons, the most serious ones highlighted as being disclosing the source of funding and follow ups after terrorism attacks."

In General (R) Pervaiz Musharraf's era of government, the Societies Registration Act (SRA) 1860 was amended after the terrorist attacks of 9/11 on US soil. This amendment made registration obligatory to review the sources of funding and maintain audit. However, the registration process resumed and received impetus after 2007. To cater for these developments, authorities drew up regulations requiring all religious institutions to be properly registered with the government and to provide clarity on some sources of financial funding. In order to encourage the registration of madrasas, the government even offered better incentives regarding financial and intellectual resources. These include training resources and educational supplies in addition to better salaries.

\section{Types of Madaris and Gender Dynamics}

Religious education is playing an effective and constructive role for the promotion of Islamic knowledge and literacy in the country. The Societies Registration Act (SRA) 1860 defines religious seminaries as those Islamic institutions, which may include dar ul aloom, jamia, schools, colleges or universities, which are operating principally for imparting shariah compliant (religious) learning and education. These institutions often provide free education, food, boarding and lodging facilities to the deserving and needy children of less-privileged urban settlements and remote areas of the country. In Pakistan, the following five wafaq's 
(schools of thought/governing bodies) stand under the umbrella of religious education.

\section{Wafaq ul Madaris al Arabia (Deobandi) \\ 2. Tanzeem ul Madaris (Barelvi) \\ 3. Wafaq ul Madaris al Salafia (Ahl-e-Hadith) \\ 4. Wafaq ul Madaris al Shia (Shia') \\ 5. Rabita ul Madaris al Islamia (Jamaat-e-Islami)}

According to Rahman, ${ }^{7}$ Waqaq ul Madaris al Arabia or Deobandi school of thought constitutes more than 70 percent of all seminaries. Rahman and Bukhari ${ }^{8}$ emphasized that role of religious seminaries in imparting education needs to be recognized and acknowledged by the government and religious activists. Seminaries must be considered a part of three tier system along with private and public institutions. ${ }^{9}$ Khalid and $\operatorname{Khan}^{10}$ are of the opinion that the religious seminaries system is divided into six major categories, responsible for social and cultural differences among people living in the society. Accordingly, such substantial uncertainty in the seminaries educational system creates hurdles and dilemmas for the government and official policy makers while assimilating the seminaries in a general policy.

A research article by Zaidi ${ }^{11}$ published in the Pakistan Education Statistics Handbook indicated atrocious facts and figures regarding Pakistan's education system. Zaidi found that out of 70 million children between the age group 5-19 years, only 28 million are enrolled in schools and colleges. He also found that the annual government education budget is appalling with a mere contribution of 2.2 percent of the gross domestic product (GDP) of Pakistan for the year 2009-10. Furthermore, the public and private education system has massive learning gaps for students in which the private sector executed much improved academic results ${ }^{12}$ while enjoying enormous profits. ${ }^{13}$ Private institutions are not affordable for the majority of the students in a country like Pakistan. This pushes a large number of participants to religious seminaries because it is the only realistic alternative to continue their education. ${ }^{14}$ The curriculum and program of study offered by most of the religious seminaries is very comprehensive. A few also teach formal education subjects such as English, General Science and Urdu in addition to Islamic courses. ${ }^{15}$

Singer, ${ }^{16}$ in his research on religious seminaries, highlighted that these Islamic education institutes are strong enough to threaten displacement of state education. Andrabi et al. ${ }^{17}$ in his research report presented to the World Bank quotes that only 29 percent students are studying in such seminaries, while 33 percent students were reported by the International Crisis Group. ${ }^{18}$ Riaz $^{19}$ showed that around 18,000 to 20,000 have been operating in religious seminaries in Pakistan, with 1.2 to 1.8 million students for the year 2007-08; even oft-quoted figure are estimates at best.

Religious seminaries are often criticized as being single sex institutes for endorsing different types of education for male and female students. Anderson et al. ${ }^{20}$ highlighted the issue through the differences in male and female curriculum 
structure, while Ali and Farooq ${ }^{21}$ say that they are devoid of secular subjects and try to domesticate women, hence disempowering them. Qasmi ${ }^{22}$ relates that it is important due to religious injunctions as well as social and educational norms. Bano and Denuelin, ${ }^{23}$ however, cover the events of Lal Masjid involving female students' aggressive protests against the government to argue that female dominant seminaries are not just instruments of female domestication but rather empowered institutions. The fact is also drawn from the earlier studies of Hetland, ${ }^{24}$ Ebrahim $^{25}$ and Butt $^{26}$ who figured that religious seminaries as a medium of the conservative approach are biased towards male students, but 30 percent of all seminaries' students are females. However, the numbers alone show that presumptions of a gender-bias are perhaps exaggerated.

At present, religious seminaries have approximately 1.8 million students enrolled in all levels of programs, out of which 0.7 million are female students and 1.1 million are male students. There are 13,240 religious seminaries operational in Pakistan, employing more than 58,000 teaching staff including majority of male teachers and around 13,000 female teachers [National Education Management Information Systems (NEMIS), 2012). This male - female students and teaching staff ratio was unheard of before the 1970s but today these religious seminaries are providing education to almost quarter of a million females. And if enrolment is choice-based, this idea loses further appeal. The Pakistani Government has also stipulated all religious educational institutes to drive out overseas students. According to NEMIS report published in 2012, out of approximately 1,700 foreign deeni madaris students, almost 1,000 had left Pakistan and arrangements had been made to deport the remaining 700 foreign students as well if they did not obtain permission to remain in Pakistan from their home governments.

\section{Relationship Between Madrasas and Other Educational Institutions}

Madrasas, in most Muslim nations today exist as components of a more extensive instructive framework. The private instructive segment gives what is thought to be a quality Western-style instruction for those who can bear the high educational costs. However, many opt for state schools on account of their low cost of education. In any case, as of late and in poorer countries, increasing expenses and deficiencies in open instructive organizations have urged individuals to send their children to madrasas. Supporters of a state instructive framework have contended that the change of existing schools or the working of new ones could offer a practical distinct option for religious-based madrasas. Others keep up that changes ought to be organized basically inside Islamic madrasas so as to guarantee balanced educational programs at these prevalent organizations. Later research likewise rejects the case for a positive causal relationship between faith schools participation and learning results in the $\mathrm{UK}^{27}$ and the US. ${ }^{28}$ 


\section{Academic Achievement in Schools}

Due to worries over quality of education in madrasahs, there are continuous calls for change in the madrasa framework in South and East Asia. What seems to be disregarded is that a noteworthy extent of madrasas working in Indonesia, Malaysia and Bangladesh are now under state control. These theological schools are managed and financed by the legislature and teach subjects like Maths, English and Science. They likewise charge lower fees and can assume a vital part in enhancing educational access among poor groups. In any case, educators in these madrasas regularly need formal preparation. These deficiencies and shortcomings together with an accentuation on the retention of religious writings imply that even students of government-perceived madrasas might linger behind their companions from non-madrasa schools as far as proficiency in comprehension and mathematical abilities are concerned. At the end of the day, these "transformed" madrasas don't offer a learning advantage like that offered by conventional schools in Pakistan and elsewhere.

In any case, the negative relationship between madrasa participation and test scores could be clarified by the way that these schools are attended mostly by youngsters from generally underprivileged backgrounds. Numerous people contend that the positive Catholic school impact is to a great extent ascribed to better students from better financial backgrounds. At the end of the day, rather than emphasize the negative impact of madrasa education, non-Muslim religions, e.g., Catholic school impact is one-sided and positive in the raw data research.

\section{Media Misrepresentation of Religious Education}

History has shown that in the West, modernization of education was used as a tool to dethrone the powerful pope. Differentiating between the religious school of thought and the secular school of thought, the Age of Enlightenment represents a time when all living things were considered mechanical objects, made up of atoms and completely devoid of spiritual significance. Following the modernization of education, science education was emphasized well into the $20^{\text {th }}$ century, producing students with knowledge of both natural sciences and social sciences. However, there was little emphasis on religious knowledge and spiritual development. This continued divergence of religion from education plays a significant part in the lack of contextual knowledge of most individuals today ${ }^{29}$ While most Western countries follow a secular school system, it is undeniable that the media has distorted the role of religious education.

Past research shows that a correlation exists between activist Islamic fundamentalism and certain religious education institutions in the country. Be that as it may, this connection has been disproportionally emphasized and highlighted by Western media trying to prosecute madrasas as being the cradle of savage religious extremism. To counter the media negativity, Western media regularly exhibits figures taking into account confounded statistics of religious educational programs, overlooking the origin of the program and misrepresenting political substances directing seminaries. ${ }^{30}$ It is fundamental to considering the reform and regulation of the madrasa system in conjunction with Pakistan's Ministry of Edu- 
cation. Similarly, diverting Western media thoughtfulness regarding advancing general changes of Pakistan's arrangement of education is essential.

Public perceptions show that the pessimism publicized in the western media has accomplished significant harm. Overemphasis on this negativity has resulted in marginalization of minority populations and the initiation of extremist perspectives. ${ }^{31}$ By giving an account of the disappointments of Pakistan's arrangement of education - its powerlessness to expand proficiency rates, its inability to enhance education, and its absence of subjects considered vital for an accomplished and productive workforce Western media might be spreading anti west feelings all through Pakistan, driving some people to look for asylum in madrasas that are more compelling in their resistance to Western obstruction. It is hence important for the Western media to consider these perspectives and redirect the media focus. Rather than emphasizing the politically motivated aspects highlighting negativities, they must direct attention to comprehensive unbiased reports which accurately reflect the values of the system and convey the compassion that is a significant part of the religion. ${ }^{32}$ In this respect it would be imperative to recognize the long history of madrasas in history and attesting their positive impact in the system of education. This approach would yield more productive results than the blind annihilation of these institutes which serve a noble purpose.

With regard to media misrepresentation it is also essential to draw attention to the functionalization of religious education institutions. The expression "functionalization" alludes to the procedure by which components of Islamic custom serve an alternative de facto purpose. ${ }^{33}$ The portrayal of madrasas in newspapers and research publications reveals that this is perhaps the best example of functionalization of a single component of religion into a means to achieve political propaganda and national security interests in a post-9/11 arena. Interestingly, the root of anti-West religious radicalization cannot be accurately traced, however research intensely focuses on this negativity without any reference to sound sources of information, a thorough analysis of madrasa educational modules and an understanding of the underlying history and current political difficulties.

\section{Concluding Remarks}

The evolution of religious education is politically motivated and misconstrued by mass media. Established as centers for education for all, privileged and underprivileged, these institutions have later become the focal point of extremist discussions. This study shows that when statistics and research are impartially analyzed, religious seminaries have had a positive impact regarding access to education for the underprivileged and empowering women. The negativity associated with this research area is the result of unbalanced focus on the destructive aspects of certain madaris, coupled with distortion by the media.

Future studies should focus on more expansive examination of this area whilst incorporating statistical analysis. Considerable effort is necessary in the study of this area, both qualitatively and quantitatively. 


\section{References and Endnotes}

1 Eric A. Hanushek, "The Failure of Input-based School Policies," Economic Journal, 113, (2003): F64-98; Erik A. Hanushek, E. and Ludger Woessmann. "The Role of Cognitive Skills in Economic Development," in Journal of Economic Literature, 46(3), (2008): 607-68.

2 William N. Evans and Robert M. Schwab, "Finishing High School and Starting College: Do Catholic Schools Make a Difference?" in Quarterly Journal of Economics, 110, (1995): 941-974; William Sander, "Catholic Grade Schools and Academic Achievement," in Journal of Human Resources, 31 (1996): 540-548; Derek A. Neal, "The Effects of Catholic Secondary Schooling on Educational Achievement," in Journal of Labour Economics, 15, (1997): 98-123; S. J. Prais, "The Superior Educational Attainments of Pupils in Religious Foundation Schools in England," National Institute Economic Review, 193, (2005): 102-105.

3 Muhammad Waqas Sajjad, "Madrasas in Pakistan: Thinking Beyond Terrorismbased Reforms," in Strategic Studies, 29(4), 2009.

4 M. Farooq, and A. Ali, "Religious Education: A Comparative Study of Girls' and Boys ' Curriculum of Pakistani Deobandi Madrasas," in Journal of Research (Humanities) Vol. 27, (2007): 47-70.

5 Salim Mansur Khalid and Muhammad Fayyaz Khan, "Pakistan: The State of Education," in The Muslim World, 96(2), (2006): 305-322; Syed Rashad Bukhari, and Khalid Rahman, "Pakistan: Religious Education and Institutions." The Muslim World, Vol. 96, (2006): 323-339; Åge Diseth, Ole-Johan Eikeland, Terje Manger, and Hilde Hetland, "Education of Prison Inmates: Course Experience, Motivation, and Learning Strategies as Indicators of Evaluation," in Educational Research and Evaluation, 14(3),(2008): 201-214.

6 Peter W. Singer, "Pakistan's Madrassahs: Ensuring a System of Education not Jihad," The Brookings Institution Analysis Paper \#1, 2001; Hussain Haqqani, A History of Madrassa Education, Education in the Muslim World: What next?, (2002). Retrieved from http://aed.org/publications/GLG EducationMuslimWorld.pdf . http://articles.timesofindia.indiatimes.com/2013-0212/mumbai/37058191_1_Madrassa-education-mainstream-educationsystem-muslimpersonal-law-board

7 Tariq Rahman, Denizens of Alien Worlds: A Study of Education, Inequality and Polarization in Pakistan (Oxford University Press, Pakistan, 2004)

$8 \quad$ Syed Rashad Bukhari and Khalid Rahman, "Pakistan: Religious Education and Institutions," 323-339.

9 Åge Diseth, Ole-Johan Eikeland, Terje Manger, and Hilde Hetland, "Education of Prison Inmates: Course Experience, Motivation, and Learning Strategies as Indicators of Evaluation," 201-214.

10 Salim Mansur Khalid and Muhammad Fayyaz Khan, "Pakistan: The State of Education," 305-322.

11 Mosharraf Zaidi, "Education Fairy Tales for Adults," The News, 28 Jul. (2009): 5.

12 Jishnu Das, Priyanka Pandey, and Tristan Zajonc, "Learning Levels and Gaps in Pakistan," World Bank Policy Research Working Paper 4067, (2006)

13 Muhammad Asadullah, "Returns to Private and Public Education in Bangladesh and Pakistan: A Comparative Analysis," in Journal of Asian Economics, 20(1), (2009):77-86.

14 Mosharraf Zaidi, "Education Fairy Tales for Adults," 5.

15 Muhammad Asadullah, "Returns to Private and Public Education in Bangladesh and Pakistan: A Comparative Analysis," 77-86. 
16 Peter W. Singer, "Pakistan's Madrassahs: Ensuring a System of Education not Jihad," The Brookings Institution Analysis Paper \#1, (2001)

17 Tahir Andrabi, Jishnu Das, Asim Ijaz Khwaja and Tristan Zajonc, "Religious School Enrollment in Pakistan - A Look at the Data," World Bank Policy Research Working Paper Series 3521, (2005).

18 C. Christine Fair, "Militant Recruitment in Pakistan: A New Look at the MilitancyMadrasah Connection," in Asia Policy, Number 4, (2007): 107-134.

19 Ali Riaz, Faithful Education: Madrassahs in South Asia (New Jersey: Rutgers University Press, 2008)

20 Anderson, Gary L. Advocacy leadership: Toward a post-reform agenda in education. Routledge, 2009.

21 M. Farooq, and A. Ali, "Religious Education: A Comparative Study of Girls" and Boys ' Curriculum of Pakistani Deobandi Madrasas," 47-70.

22 Qasmi, M. K. Madrasa Education - its Strengths and Weaknesses. New Delhi: Manak Publications, 2005 (2005)

23 Séverine Deneulin and Masooda Bano, "Religion in Development: Education and Dialogue," Paper for a seminar series on 'Religion and Development' University of Copenhagen, March 4. (2009).

24 Åge Diseth, Ole-Johan Eikeland, Terje Manger, and Hilde Hetland, "Education of Prison Inmates: Course Experience, Motivation, and Learning Strategies as Indicators of Evaluation," 201-214.

25 Ebrahim, Z. "Religious Schools - Boon or Bane?” IPS News, March 25, (2008).

26 Riazat Butt, "All-Female Madrasas Boom in Pakistan: The Next Generation of Sectarian and Jihadi Terrorists?" Guardian. 14 May, 2009.

27 Gibbons, Stephen, and Olmo Silva. "School quality, child wellbeing and parents' satisfaction." Economics of Education Review 30, no. 2 (2011):

28 Gihleb, Rania, and Osea Giuntella. "Nuns and the effects of Catholic schools: Evidence from vatican II." (2013). Jepsen, Christopher. "The effectiveness of Catholic primary schooling." Journal of human Resources 38, no. 4 (2003): 928-941.

29 Hefner, Robert W., and Muhammad Qasim Zaman. Schooling Islam: The culture and politics of modern Muslim education. Princeton University Press, 2007.

30 Patrick J. McEwan, "The Effectiveness of Public, Catholic, and Non-Religious Private Schools in Chile's Voucher System.” Education Economics, 9(2), (2001): 103128

31 Shibley Telhami, The Stakes: America in the Middle East: The Consequences of Power and the Choice for Peace (Cambridge, MA: Westview Press, 2002)

32 Ibid.

33 Hefner, Robert W. "Religious resurgence in contemporary Asia: Southeast Asian perspectives on capitalism, the state, and the new piety."The Journal of Asian Studies 69, no. 04 (2010): 1031-1047.

\section{Selected Bibliography}

1. Andrabi, Tahir, Tahir Andrabi, Jishnu Das, Asim Ijaz Khwaja and Tristan Zajonc. "Religious School Enrollment in Pakistan - A Look at the Data." World Bank Policy Research Working Paper Series 3521, 2005.

2. Asadullah, Muhammad Niaz. "Returns to Private and Public Education in Bangladesh and Pakistan: A Comparative Analysis." Journal of Asian Economics, 20(1), (2009):77-86. 
3. Bachelard, Michael. "Indonesia's Jihad Factories: Uncovering Nurseries of Terrorism's Next Generation." The Sydney Morning Herald, October 7, 2012.

4. Bano, Masooda and Séverine Deneulin. "Religion in Development: Education and Dialogue. In Religion and Development." Paper for a seminar series on 'Religion and Development' University of Copenhagen, March 4. 2009.

5. Bukhari, Syed Rashad and Khalid Rahman, "Pakistan: Religious Education and Institutions.” The Muslim World. Vol. 96, (2006): 323-339.

6. Butt, Riazat. "All-Female Madrasas Boom in Pakistan: The Next Generation of Sectarian and Jihadi Terrorists?" Guardian. 14 May, 2009.

7. Das, Jishnu. Priyanka Pandey, and Tristan Zajonc. "Learning Levels and Gaps in Pakistan." World Bank Policy Research Working Paper 4067, (2006).

8. Diseth, Åge, Ole-Johan Eikeland, Terje Manger and Hilde Hetland. "Education of Prison Inmates: Course Experience, Motivation, and Learning Strategies as Indicators of Evaluation. Educational Research and Evaluation, 14(3),(2008): 201-214.

9. Ebrahim, Z. "Religious Schools - Boon or Bane?" IPS News, March 25, 2008.

10. Encyclopaedia of Islam, new edition (Leiden: E.J. Brill, 1965-); "Madrasah," in the Oxford Encyclopaedia of the Modern Islamic World. New York: Oxford Univ. Press, 1995.

11. Evans, W. N., and Robert M. Schwab. "Finishing High School and Starting College: Do Catholic Schools Make a Difference?" Quarterly Journal of Economics, 110, (1995): 941-974,

12. Fair, Christine. "Militant Recruitment in Pakistan: A New Look at the MilitancyMadrasah Connection." Asia Policy, Number 4, (2007): 107-134.

13. Farooq, M. and Ali, A. "Religious Education: A Comparative Study of Girls' and Boys' Curriculum of Pakistani Deobandi Madrasas." Journal of Research (Humanities) Vol. 27, (2007): 47-70.

14. Griswold, Eliza. “The Next Islamist Revolution?” New York Times; Magazine Desk, January 23, 2005.

15. Hanushek, Eric A. and Ludger Woessmann. "The Role of Cognitive Skills in Economic Development." Journal of Economic Literature, 46(3), (2008): 607-68.

16. Hanushek, Eric. "The Failure of Input-based School Policies." Economic Journal, 113, (2003): F64-98.

17. http://www.aepam.edu.pk/

18. Hwang, Julie Chernov. "Terrorism in Perspective: An Assessment of "Jihad Project" Trends in Indonesia." Asia Pacific Issues No. 104. Honolulu: East-West Center, 2012.

19. Jain, S. Muslims and Modernization: A study of their Changing Role, Structure and Norms in an Urban Setting. Jaipur: Rawat Publications, 1986.

20. Khalid, Salim Mansoor, and Muhammad Fayyaz Khan, Pakistan: The State of Education. The Muslim World, 96(2),(2006): 305-322.

21. McEwan, Patrick J. "The Effectiveness of Public, Catholic, and Non-Religious Private Schools in Chile's Voucher System." Education Economics, 9(2), (2001): 103128.

22. Neal, Derek A. "The Effects of Catholic Secondary Schooling on Educational Achievement." Journal of Labour Economics, 15, (1997): 98-123.

23. Prais, S.J. "The Superior Educational Attainments of Pupils in Religious Foundation Schools in England." National Institute Economic Review, 193, (2005): 102-105.

24. Qasmi, M. K. Madrasa Education - its Strengths and Weaknesses. New Delhi: Manak Publications, 2005. 
25. Rahman, Tariq. Denizens of Alien Worlds: A Study of Education, Inequality and Polarization in Pakistan. Oxford University Press, Pakistan, 2004.

26. Riaz, A. Faithful Education: Madrassahs in South Asia. New Jersey: Rutgers University Press, 2008.

27. Sajjad, Muhammad Waqas. "Madrasas in Pakistan: Thinking Beyond Terrorismbased Reforms." Strategic Studies, 29(4), 2009.

28. Sander, William. "Catholic Grade Schools and Academic Achievement." Journal of Human Resources, 31 (1996): 540-548.

29. Singer, Peter. "Pakistan “s Madrassahs: Ensuring a System of Education not Jihad." The Brookings Institution Analysis Paper \#1, 2001.

30. Strengthening Education in the Muslim World, USAID Issue Paper No. 2, June 2003.

31. Telhami, Shibley. The Stakes: America in the Middle East: The Consequences of Power and the Choice for Peace. Cambridge, MA: Westview Press, Cambridge, 2002.

32. Weaver, Mary Anne. "Children of the Jihad." New Yorker, June 12, 1995.

33. Zaidi, Mosharraf. "Education Fairy Tales for Adults." The News, 28 Jul. (2009): 5. 